Chilonycteridae. Trans. Kansas Acad. Sci., 71: 509-520. - Ritchie J. \& Edwards A. J. H., 1913: On the occurrence of functional teeth in the upper jaw of the Sperm Whale. Proc. r. Soc. Edinburgh, 33: 166-168. - Ruprecht A., 1965a: Anomalies of the teeth and asymmetry of the skull in Erinaceus europaeus Linnaeus, 1758. Acta theriol., 10:234-236. - Ruprecht A., 1965b: Supernumerary premolar in Mustela putorius Linnaeus, 1758. Acta theriol., 10: 242. - Saarenmaa L., 1951: The origin of the supernumerary teeth. Acta odont. scand., 9: 293-303. Schwartz J. H., 1974: Observations on the dentition of the Indriidae. Amer. J. phys. Anthrop., 41: 107-114. - Sheppe W., 1964: Supernumerary teeth in the deer mouse, Peromyscus. Z. Säugetierk., 29: 33-36. - Simpson G. G., 1946: Palaeogale and allied early mustelids. Amer. Mus. Novit., 1320: 1-14. - Sofaer J. A. \& Shaw J. H., 1971: The genetics and development of fused and supernumerary molars in the rice rat. J. Embryol. exp. Morph., 26: 99-109. - Steele D. G. \& Parama W. D., 1981: Frequencies of dental anomalies and their potential effect on determining MNI counts. Plains Anthrop., 26-91: 51-54. - Stein G. H. W., 1963: Anomalien der Zahnzahl und ihre geographische Variabilität bei Insectivoren: II Maulwurf, Taipa europaea L. Mitt. zool. Mus. Berlin, 39: 223-240. - Taylor R. M. S., 1971: Dental report on archaeological material from Tonga. Aust. dent. J. 16: 175-181. - Weber M., 1904: Die Säugetiere. Verlag von Gustav Fischer: I-XII+1-866. Jena. - Wing E. S., 1965: Abnormal dentition in several whitetailed deer jaws. J. Mammal., 46: 348-350. - Wolsan M., 1983: Ancestral characters in the dentition of the weasel Mustela nivalis L. (Carnivora, Mustelidae). Ann. zool. fenn., 20: 47-51. - Wolsan M., 1984: Concerning the variation in the number, shape and size of incisors in fissiped carnivores. Acta zool. cracov., 27: 107-119. - Ziegler A. C. 1971: A theory of the evolution of therian dental formulas and replacement patterns. Quart. Rev. Biol., 46: 226-249. - Zurowski W., 1970: Additional molar in European red deer. Acta theriol., 15: 523-525.

Accepted, November 5, 1983.

\title{
Possibility of Freemartinism in Roe Deer ${ }^{1}$
}

\author{
MOZLIWOSC WYSTEPOWANIA FRYMARTYNIZMU U SARNY
}

Paweł S. SYSA \& Jan KAEUZIŃSKI

\begin{abstract}
Sysa P. S. \& Kałuziński J., 1984: Possibility of freemartinism in roe deer. Acta theriol., 29, 10: 133-137 [With Plate I]

Cytogenetic analysis was made in female roe deer, Capreolus capreolus (Linnaeus, 1758), belonging to members of heterosexual triplets. Lymphocytic chimerism was not discovered, the karyotype being defined as $70, X X$. The result obtained justifies the assumption that in cases of twin or multiple pregnancy of unlike sexes in the roe deer there is no development of infertility in the females etiologically similar to the freemartinism syndrome in domestic cattle.

[Warsaw Agric. Univ., Faculty of Veterinary Medicine, 02-766 Warszawa, ul. Nowoursynowska 166 (PS); Polish Hunting Association. 62-055 Czempiń, Poland (JK)]
\end{abstract}

${ }^{1}$ Praca wykonana w ramach problemu MR.II.19 koordynowanego przez SGGW-AR w Warszawie. 


\section{INTRODUCTION}

The freemartinism syndrome observed in domestic ruminants (particularly in cattle, and sporadically in goats and sheep) develops in females born from twin pregnancies when their co-twin during the embryonic period is a male (Lillie, 1916; Balbierz, 1971; Jost et al., 1973a; Bielańska-Osuchowska, 1977). This phenomenon consists in the placentas of the embryos connecting by means of vascular anastomoses. In consequences of this connection motile embryonic tissues, particularly haemopoietic tissues, migrate between the embryos. It has been assumed that gonocytes also migrate in this way. At the same time reciprocal reaction on each other of hormonal and immunological systems takes place in the twins of the embryonic period, causing disturbance of the formation of gonads and elements of the reproductive system originating from Müllerian ducts in the female embryo (Jost et al., 1973; Sysa et al., 1980). The effect of these processes consists in various kinds of defects in development and structure of the genital system in females, usually leading to their infertility. In domestic cattle the basic cause of the phenomenon described above is the failure to form of the interplacental barrier in such cases.

This phenomenon has not been diagnosed in wild ruminants, this including the roe deer, which in this respect is a peculiar species, as it has been found that twin and multiple pregnancies occur in as many as $94 \%$ of the females (Strandgaard, 1972a). In the experimental hunting area at Czempin, about $82 \%$ of the young originate from bigeminal and multiple pregnancies (Kałuźinski, 1982). Similar results to the above have been obtained by other researchers. A considerable percentage of such pregnancies (about 50\%) consist of embryos of unlike sex (Borg, 1970; Strandgaard, 1972b). It is therefore necessary to ascertain whether a developmental syndrome similar to freemartinism in domestic ruminants forms in the roe deer.

The purpose of the present study was to determine whether the phenomenon of lymphocytic chimerism, which is an indicator of the formation of vascular placental fusions, takes place in females of the roe deer from multiple pregnancies in which a male was a partner of the embryonic period.

\section{MATERIAL AND METHODS}

The study material consisted of blood samples collected from two female roe deer Capreolus capreolus (Linnaeus), 1758) born from multiple pregnancies. Both the females originated from litters consisting of three fawns, as follows: 2 우, $\sigma^{x} ;$ 우 $20^{x}$. The fawwns were born in the experimental enclosure of the Polish Hunting Association Research Station at Czempiń (Poznań voivodship).

Blood was sampled in vivo from the jugular vein in the eleventh month of the females' life. Heparin was added to prevent coagulation. Cell culture was set up from lymphocytes obtained after spontaneous sedimentation. Parker's medium (TC 199), enriched to $10 \%$ with autological serum, was used for the cell culture. Wellcome's phytohaemagglutinin and fazeolin (FL 7), produced by the Animal Husbandry Institute at Balice, were used as up growth and cell 
division stimulators. Cell culture was continued for 72 hours, adding Colchineos $\left(0.001 \mathrm{mg} / \mathrm{cm}^{3}\right.$ of culture) $1 \frac{1 / 2}{2}$ hours before the end of the cell cultivation. The cell suspension was subjected to the action of hypotonic fluid $(0.05 \mathrm{M} \mathrm{KCl})$ and fixed in three changes of the fixative fluid, which was a mixture of methyl alcohol with glacial acetic acid, in ratio of 3:1. A drop of the fixed cell suspension was transferred to a slide and left to air-dry. The preparations were given routine staining with $5 \%$ Giemsa stain in a Sörensen buffer with $\mathrm{pH} 6.8$. Observation of metaphasal plates (200 per each female) was made either directly under a microscope or from photographic prints.

\section{RESULTS}

Analysis of the metaphasal plates of female roe deer shows that the chromosome sets of these individuals consist of 70 chromosomes. Sixty eight of them are acrocentric structures of different size, and the other two large submetacentric chromosomes, which are two $X$ sex chromosomes (Figs. 1, 2-Plate I). In the females examined only metaphasal plates with the $70, X X$ chromosome set were encountered.

\section{DISCUSSION}

In roe deer the chromosome set has been defined as $2 n=70$ by Gustavsson (1965), Amrud \& Nes (1966), Wurster \& Benirschke (1967) and Hsu \& Benirschke (1968). Somatic chromosomes in this species of animal take on the form of acrocentric structures of different size, 68 in number. The $X$ heterochromosome is a large submetacentric chromosome, while Y sex chromosome is shaped like a small subtelocentric chromosome. In the Siberian roe deer (Capreolus c. pygargus Pallas, 1771), in addition to the chromosome set typical of the roe deer there are also microchromosomes, the so-called B-chromosomes, varying in number, up to 10 in the somatic cell (Sokolov et al., 1978, Zernahle, 1980). The biological importance of these microchromosomes has not as yet been determined.

On account of the occurrence of a distinct difference between the morphology of sex chromosomes $X$ and $Y$, which in the roe deer is a small and subtelocentric structure, it would be easy to diagno 3 a state of lymphocytic $X X / X Y$ chimerism in individuals of the species examined. In addition to typical metaphasal plates of the female individual $(70, X X)$ cells would appear containing $X Y$ chromosomes derived from the male partner from the period of intrauterine development, if formation of vascular connections in the placentas had taken place between them. The phenomenon of chimerism of $X X / X Y$ chromosomes is easy to trace, e.g. in the case of domestic cattle. It was even assumed that there may be a correlation between the percentage - of cells of the male co-twin and the degree of changes caused in the development of the genital organs of heifers. It turned out that there are no ground; for this suggestion (Vigier et al., 1972, Marcum et al., 1975). Blood cells do not take part in controlling development of the reproductive system, hence there is no simple correlation between the percentage of $X Y$ cells and deformation of the female's reproductive system. The genetic constitution plays the chief part and is expressed by 
immunological-tissue reaction and hormonal effects (Jost et al., 1973b, Ohno, 1979).

The failure to discover $X Y$ cells in the females examined does not completely rule out the possibility of active contact between the placentas and consequent reciprocal reaction of the embryos on each other. This might have been caused by a very weak invasion of cells of the haemopoietic tissue of the male, which in relatively small number might migrate between the foetuse; and have been omitted in the study material. The lack of perceptible $X Y$ cells does not completely exclude vascular contact, migration of connective tissue cells and hormonal reaction between foetuse 3 .

Borg's (1978) and Strandgaard's (1972b) data and the present authors' unpublished observations indicate that in about $50 \%$ of twin and multiple pregnancies individuals of unlike sex are born. If then in female roe deer originating from twin or multiple pregnancies, the partner of which during the embryonic period was a male, the phenomenon of freemartinism would be general, the proportion of unfertilized females in the population would be far higher than that found by Kałuzinski (1982), i.e. only $6.5 \%$ of unfertilized female;, whereas in the case of occurrence of freemartinism it could have been expected that at least $35-40 \%$ of all female roe deer in the population would be completely unfertilized. Strandgaard (1972a) observed a slightly smaller percentage of unfertilized females in the population than that found by Kałuzinski (1982).

All the foregoing therefore indicates that the interplacental barrier in roe deer is most probably more hermetic than in other species with placentas of a similar type, such as domestic cattle, sheep or goats.

On the basis of analysis of chromosomes from females originating from triplet pregnancies of unlike sex and observations of the fertility of roe deer in populations, it may be assumed that there is little likelihood of the occurrence in this species of infertility etiologically connected with twin pregnancies of unlike sex, and correspond in character to the etiology of the freemartinism syndrome in cattle.

Observations up to the present indicate that in the roe deer, presumably by means of evolution, certain biological mechanisms have formed which encourage simultaneous ovulation of several egg cells, limiting early elimination of additional embryos and governing formation of barriers isolating foetal membranes of neighbouring embryos, all with the purpose of favouring attainment of higher fertility in the population.

\section{REFERENCES}

Amrud J. \& Nes N., 1966: The chromosomes of the roe deer (Capreolus capreolus). Hereditas, 56: 217-220. - Balbierz H., 1971: Free-martinizm - jedną z postaci niepłodności samic zwierząt domowych. Medycyna Wet., 27: 449-452. - Bielańska-Osuchowska Z., 1977: Embriologia. Państw. Wyd. Roln, i Leśne: 1-332. Warszawa. - Borg K., 1970: On mortality and reproduction of roe deer in Sweden during the period 1948-1969. Viltrevy, 7: 1-149. - Gustavsson I., 1965: Chromosome studies in five species of deer representing the four genera Alces, Capreolus, Cervus and Dama. Mammalian Chromosomes Newsletter, 18: 149. - Hsu T. C. \& Benirschke K., 1968: Atlas of Mammalian Chromosomes. Springer Verlag, Berlin-Heidelberg-New York. - Jost A., Vigier B., Prepin J. \& Perchellet J.-P., 1973a: Le developpement de la gonade des freemartins. Ann. Biol. anim. Bioch. 


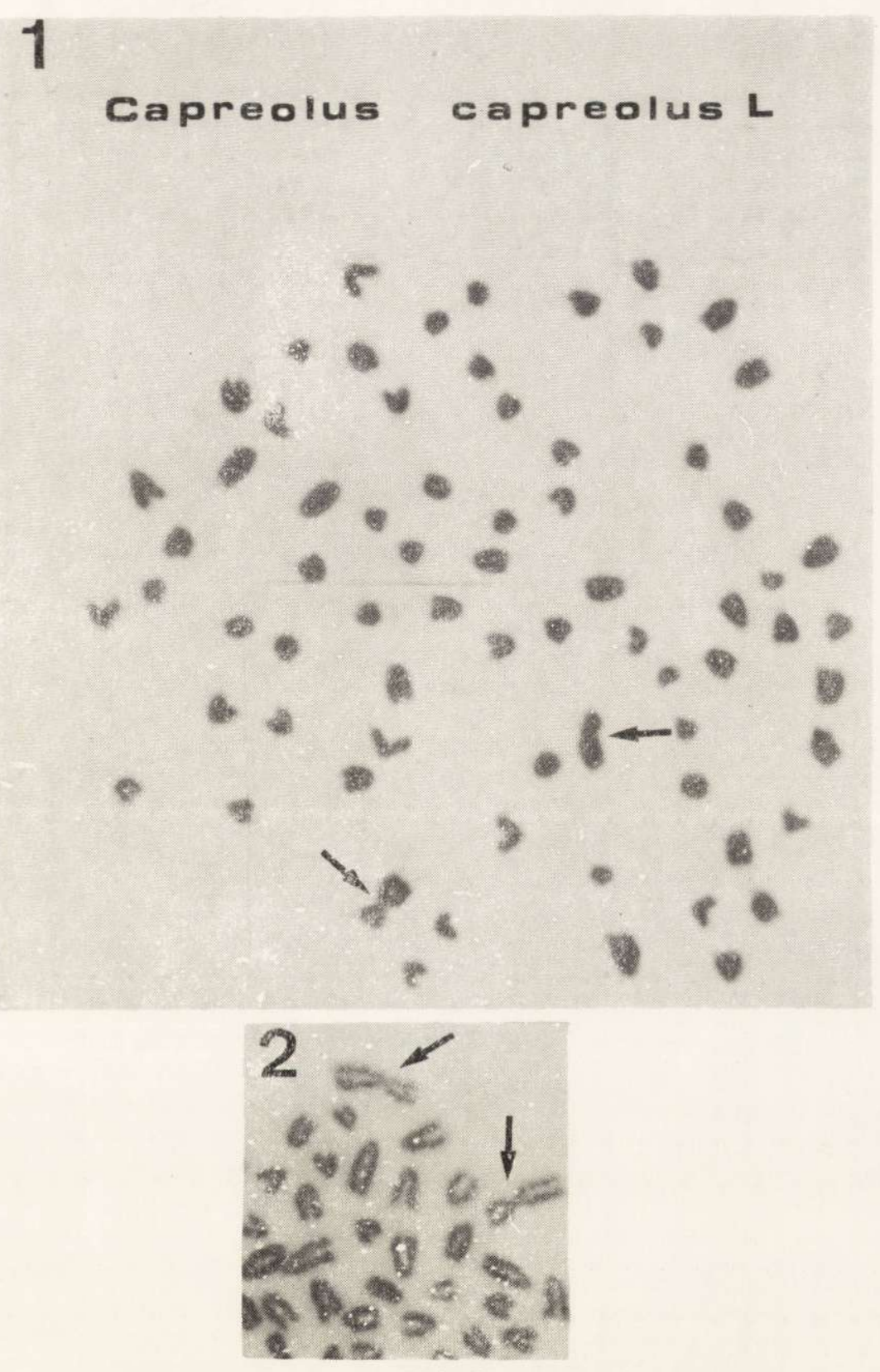

Plate I

Fig. 1. Metaphasal plate of a female roe deer born as one of triplets $\left(q \circ \sigma^{7}\right)$. $70, X X$ karyotype. The $X$ sex chromosomes are indicated by arrows.

Fig. 2. Part of a metaphasal plate of a female roe deer born as one of a pluriparous pregnancy $\left(\sigma^{x} \sigma^{x}\right)$. The $X$ sex chromosomes are indicated by arrows. 
Biophys., 13: 103-114. - Jost A., Vigier B., Prepin J. \& Prechellet J.-P., 1973b: Studies on sex differentiation in mammals. Rec Prog. Horm. Res., 29: 1-41. Kałuziński J., 1982: Dynamics and structure of field roe deer population. Acta theriol., 27: 385-408. - Lillie F. R., 1916: Theory of the Freemartin. Science, 43: 611-613. - Marcum J. B., Lasley J. F. \& Day B. N., 1972: Variability of sex chromosome chimerism in cattle from heterosexual multiple births. Cytogenetics, 11: 388-399. - Ohno S., 1979: Major sex-determining genes. Springer Verlag, Berlin, Heidelberg, New York. - Strandgaard H., 1972a: The roe deer (Capreolus capreolus) population of Kalø and the factors regulating its size. Danish Rev. Game Biol., 7: 1-204. - Strandgaard H., 1972b: An investigation of corpora lutea, embryonic development, and time of roe deer (Capreolus capreolus) in Denmark. Danish Rev. Game Biol., 6: 1-22. - Sokolov V.E., Orlov V. N., Chudinovskaja G. A., \& Danilkin A. A., 1978: Differences in chromosomes between two subspecies Capreolus capreolus L. and C. c. pygargus Pall. Zool. Ż., 57: 1109-1112. - Sysa P.S. Sławomirski J. \& Kuńska A., 1980: Cytogenetyczne badania nad frymartynizmem u bydła. Medycyna Wet. 36: 225-228 - Vigier B., Prepin J. \& Jost A., 1972: Absence de correlation entre le chimerisme $X X / X Y$ dans le foie et les premiers signes du freemartinisme chez le foetus de Veau. Cytogenetics, 11: 81-101. Volobujev V. T.: The B-chromosome system of mammals. Genetica, 52/53: 33-337. - Wurster D. \& Benirschke K. 1967: The chromosomes of twenty-three species of the Cervoidea and Bovoidea. Mammalian Chromosomes Newsletter, 8: 226. Zernahle K., 1980: Zytogenetische Untersuchungen am Europäischen Rehwild (Capreolus c. capreolus L., 1758), Sibirschen Rehwild (Capreolus c. pygargus, Pallas 1771) und deren Bastarden. Beiträge zur Jagd- und Wildforschung, 11: 304-309.

Accepted, November 20, 1983.

\title{
Food of the Long Eared Hedgehog in Ravines Near Agra
}

\author{
POKARM JEZA USZATEGO W OKOLICACH AGRY
}

\section{U. K. MAHESHWARI ${ }^{1}$}

Maheshwari U. K., 1983: Food of the long eared hedgehog in ravines near Agra. Acta theriol., 29, 10: 137-140 [With 2 Tables]

Annual and seasonal food composition of 165 long eared hedgehog Hemiechinus auritus collaris (Gray, 1830) studied from their stomach contents revealed that the main diet composed of insects $(47.4 \%$ by number method and $39.74 \%$ by weight method). Beetles constituted more than $75 \%$ of the insect food. Oligochaetes, amphibians, reptiles and mammals also occurred in low proportion $(7-10 \%)$. It appears that the food of the hedgehogs is related to the availability of the prey.

[Department of Zoology, Agra College, Agra 282 002, India].

\section{INTRODUCTION}

The long eared hedgehog Hemiechinus auritus collaris (Gray, 1830) is fairly common in chalesar ravine; near Agra, India. It has been

\footnotetext{
1 Present address: 16/24, Rawat Para, Agra - 282003, India.
} 